\title{
Fungi: Diversity in India and its Potential Applications
}

\author{
Kiranpreet Kaur, Ramandeep Kaur, Shivani Thakur, Anuj Kumar, \\ Harpreet Singh and Rajnish Kumar Verma*
}

Department of Botany, Dolphin PG College of Science \& Agriculture, Chunni Kalan, Punjab, 140307, India

*Corresponding author

\begin{abstract}
A B S T R A C T
Keywords

Fungi Diversity in India, Hyphomycetes

Article Info

Accepted:

20 January 2019

Available Online:

10 February 2019

Fungi are eukaryotic achlorophyllous organisms live in wide array of habit and habitats on earth. Being non-photosynthetic fungi exhibit anabsortive mode nutrition, which lead to Saprophyte, Parasite or Mutualistic existence. Fungi is second largest group of organisms outnumber by insects only. Recent estimate suggested that, around 2.2-3.8 million fungi are there on planet. Fungi are known to produce many antibiotics, bio-active molecules, organic acids and secondary metabolites etc. Fungi so far have been exploited very poorly and yet have a huge potential in bio-control, bioremediation and novel compound.
\end{abstract}

\section{Introduction}

Fungi are eukaryotic achlorophyllous organisms live in wide array of habit and habitats on earth. Being achlorophyllous fungi exhibit an absortive mode nutrition, which lead to Saprophyte, Parasite or Mutualistic existence. As a saprophyte fungi along with bacteria bring out complete mineralization of plant and animal remains. As a parasite fungi cause many diseases in animals and plants. As Mutualistic fungi live in intimate association with other organisms. Fungi are almost cosmopolitan in their distribution and they exploit the diverse array of macro and micro nutritional niches. The most important factor influencing the distribution and life style of fungi is their heterotrophic nutrition (Cook and Rayner, 1984).

\section{Fungal diversity}

Fungi are the largest and diverse group of organisms out number by insects only Tropical belts of the world with high rainfall, humidity and temperature, is known to encompass the most diverse habitats and considered to have the highest diversity for most groups of organisms be it plants, animals or microorganisms and fungi (Pianka, 
1966; Hawksworth, 1991; Hillebrand, 2004; Arnold and Lutzoni, 2007). Only 5-10\% of fungal species have been described, documented (Hawksworth, 2001). Many estimates have been put forward to elucidate the Fungal species diversity in the world, few are listed in table 1.

\section{Fungal diversity in India}

\section{Microfungi}

Studies on fungi in India began with advent of foreigners, mainly from Britain who collected fungi and sent specimens to European laboratories for identification. The earliest record of Hyphomycetes in India was made by Corda (1837). Further the studies of Indian fungi were continued by Barcklay and Cunningham. Barcklay (1886) contributed to knowledge of the rusts occurring in the vicinity of Shimla. Cunningham (1927) contributed to Orders Mucorales, Ustilaginales and Uredinales.

Sir E. J. Butler who has been regarded as the 'Father of Indian Mycology', to initiate and organize large-scale mycological and phytopathological research in India. $\mathrm{He}$ founded the Herbarium Cryptogamae Indiae Orientalis (HCIO), a national fungal herbarium facility Pusa, Bihar in 1905. In 1934, the HCIO was shifted to the Division of Mycology and Plant Pathology, Indian Agricultural Research Institute, New Delhi. Butler and his associates compiled 'Butler and Bisby's (1931) 'The Fungi of India', which has been revised several times and further updated by Mukerji and Juneja, 1974; Sarbhoy et al., 1986, 1996; Jamaluddin et al., 2004. Mitra (1921, 1923, 1931) studied Helminthosporium species on cereals. Mitter and Tandon (1930-38) named and described many species from India. Since then several interesting hyphomycetes were reported by various workers from different parts of the country (Mundkur, 1938; Ramakrishnan, 1941, 1949).

India is one of the richest reservoirs of biodiversity in Asia and can be considered as a center of research of hyphomycetes diversity with high proportion of genera and species particularly of tropical species first described in this country (Bilgrami et al., 1991, Jamaluddin et al., 2004). Comprehensive account on hyphomycetous fungi of India are now available (Subramanian, 1971, 1983; Rao and de Hoog, 1986; Mukerji and Manoharachary, 2010; Bhat, 2010; Kamal, 2010).

The earliest available record of coelomycetes is based on the publication by Léveillé (1846). He published the first report of a pycnidial fungus, Ascospora sordidula from India on the leaves of Saussurea sp., which was changed to Septoria sordidula by Saccardo in 1884. Subramanian and Ramakrishnan (1952, 1953b) were the first Indian workers to initiate studies on this group. They described a coelomyceteous fungus Plagionema with lateral and apical appendaged conidia, which was later reduced to synonymy with Ciliochorella Syd. (Subramanian and Ramakrishnan, 1953). They further contributed to the taxonomy of coelomycetes with the descriptions of some taxa (Subramanian and Ramakrishnan, 1954, 1955, 1958).

Mathur (1979) in his book "The Coelomycetes of India" provided a checklist of coelomycetes collected/reported from India during 1846-1977. He enlisted 235 genera, 1527 species and 33 varieties.

Muthumary and co-workers (Muthumary 1986 a, b, c, 1987 a, b, c, 1988; Muthumary and Sutton 1986; Muthumary et al., 1986; Muthumary and Masilamani 1989) described some new species and recorded many fungi 
from India. Muthumary (1999) published the monograph "First contribution to a Monograph of Septoria Species in India". She provided a key to the 83 species included in the monograph based on host taxonomy and conidial measurements. Muthumary (2013) in her book "Indian Coelomycetes" gave description and illustrations of 142 species spreading in 78 genera.

\section{Macrofungi}

Different workers had studied diversity of macrofungi From time to time from different parts of India. Several edible fungi have been identified from Punjab by Chahal (1963). Thirty species of macrofungi belonging to 26 genera spreading over 17 families have been reported by Tapwal et al., (2013) from Jeypore Reserve Forest located in Assam. In Gujrat and Jammu and Kashmir major work on macrofungi was carried out by Chandulal et al., (2013) and Anand et al., (2014) respectively. Karwa and Rai (2010) reported 153 species of mushrooms from Central India (Maharashtra). Pandey and his coworkers also done an intensive survey to identify mycofloral diversity of Central India and worked on different aspects of it (Sharma et al., 2009a, b; 2011a, b; Dwivedi et al., 2012). 778 species of macrofungi belonging to 101 genera of 43 families reported by Swapna et al., (2008) from Karnataka. Soosairaj et al., Thiribhuvanamala et al., (2013) identified 23 species macrofungi from Tamil Nadu. 200 species of wood rotting non-gilled Agaricomycotina which belongs to 27 families spreading over 100 genera have been reported by Prasher and Lalita 2014 from Uttarakhand. Semwal et al., (2014) recorded 23 species of mushrooms of which twenty one were Basidiomycetes and two were found to be Ascomycetes. 13 species of macrofungi belonging to 10 genera and 9 families from Pune and Western Ghats of Mahabaleshwar and Mulshi of Maharashtra was recorded by
Senthilarasu (2014). 90 species belonging to 19 families were recorded from Karnataka of which 28 species were found to be recorded for the first time from India Pushpa and Purushothama (2012). Prasher et al., (2012) recorded 13 species of polyporoid fungi belonging to 5 families and 10 genera from Himachal Pradesh. Dhingra et al., (2014) reported 295 taxa belonging to 89 genera of non-poroid Agaricomycetous fungi from Himachal Pradesh.

However, with the advent of the molecular fungal taxonomy a natural classification based on molecular fungal taxonomy has evolved (Hibbett et al., 2007, Shenoy et al., 2007, Thambugala et al., 2015, Tian et al., 2015 and Wang et al., 2015). This has resulted in the intergeneric shifting of species, introduction of new genera for correct placement of species which have been already described, as well as reassignment of genera to different families, orders and classes.

\section{Significance of fungi}

Fungi have also been used in commercial production of lignocellulolytic enzymes e.g. laccases, manganese peroxidise and lignin peroxidase (Pointing et al., 2005; Baldrian, 2006; Safari Sinegani et al., 2006; Hoffmeister and Keller, 2007; Kaushik and Malik, 2009; Maciel et al., 2010 and Moore et al., 2011); bio-active molecules (Hanson, 2008; Thirunavukkarasu et al., 2012 and Arora et al., 2012) and organic acids (Jakubowska, 1977 and Mäkelä et al., 2002).

Many filamentous and basidiomycetes fungi have been known to produce organic acids viz. acetic, citric, tartaric, malic, lactic, succinic, oxalic and gluconic acid (LopezGarcia, 2002; Mäkelä et al., 2002; Magnuson and Lasure, 2004 and Mandal and Banerjee, 2006; Liaud et al., 2014). Various fungi such as Aspergillus nigerPycnoporus sanguineus 
and Talaromyces helices has been used for the biosorption of heavy metals (Romero et al., 2006; Yahaya et al., 2009 and Zeng et al., 2015)

Many fungi belonging to ascomycetes and basidiomycetes have a potential to act as an antiviral agent against EV7, HIV-1, EV71,
HSV-1, H1N1and H3N2 viruses (Ma et al., 2013; Li et al., 2014; Zhao et al., 2017; Pang et al., 2018). The antiviral activity of these fungi is mainly because of the presence of polysaccharides in mycelium and fruiting bodies, and synthesis of triterpenoid secondary metabolites (Chen et al., 2012; Rincão et al., 2012)

Table.1 Popular estimates of species diversity of fungi

\begin{tabular}{|c|l|l|}
\hline Sr. no. & No. & Reference \\
\hline 1. & $1,50,000($ Estimate $\mathrm{G})$ & Hawkswoth $(1991)$ \\
\hline 2. & $2,270,000$ & Hawkswoth $(2001)$ \\
\hline 3. & $3,500,000-5,100,000$ & O' Brien et al., $(2005)$ \\
\hline 4. & 712,000 & Schmit and Mueller $(2007)$ \\
\hline 5. & $611,000( \pm$ SE $=297,000)$ & Mora et al., 2011 \\
\hline 6. & $2.2-3.8$ million & Hawksworth and Lucking $(2017)$ \\
\hline
\end{tabular}

In conclusion, huge research has been made in the understanding of the fungi in India. Many new species of fungi have been established for the region, but much work remains to be undertaken. Many of the fungi are known to produce various therapeutic metabolites with high biological activities. So it became very important to properly characterize not only these compounds, but to carefully identify the species names, so that researchers can identify and screen taxa for future biotechnological applications. Fungi so far have been exploited very poorly and yet have a huge potential in biocontrol, bioremediation and novel compound. With such high novelty, there is a need for extensive research to exploit the biotechnological potential of these fungi.

\section{References}

Anand N., Mathur A. and Chowdhary P.N. (2014) First report of macrofungal biodiversity in Rajouri dist. (J\&K), India. World Journal of Pharmacy and Pharmaceutical Sciences 3(12): 1385-
1402.

Arora D.S., Chandra P. and Kaur G.J. (2012). Optimization and assay of antioxidant potential of two Penicillium spp. by different procedures. Current Biotechnology. 1(1): 2-10.

Baldrian P. (2006). Fungal laccasesoccurrence and properties. FEMS Microbiology Reviews. 30(2): 215-242.

Bhat D.J. (2010). Fascinating microfungi (Hyphomycetes) of Western GhatsIndia. Broadway Book Center Goa. 221pp.

Bilgrami K.S., Jamaluddin and Rizwi M.A. (1991). Fungi of India List and References. Today and tomorrow's Printers and Publishers, New Delhi, India. 798p.

Butler E.J. and Bisby G.R. (1931). The fungi of India. Science Monograph I. Imperial Council for Agricultural Research in India.

Chahal D.S. (1963) Some edible mushroom of Punjab. Punjab Hort. J 326-29

Chandulal K., Gopal C. and John P. (2013) Studies on biodiversity of fleshy fungi 
in Navsari (South Gujarat), India.Int $\mathbf{J}$ Biodivers Conserv 5(8): 508-514

Chen, S., Xu, J., Liu, C., Zhu, Y., Nelson, D. R., Zhou, S., et al., (2012). Genome sequence of the model medicinal mushroom Ganoderma lucidum. Nat. Commun. 3:913. doi: 10.1038/ncomms1923

Cunningham G.H. (1927). Fifth supplement to the Uredinales and Ustilaginales of New Zealand. Transactions and Proceedings of the New Zealand Institute. 58(1-2):47-50

Dhingra G. S., Singh A.P., J. Kaur, Kaur P. H., Rani M., Sood S., Singla N., Kaur H., Jain N., Gupta S., Kaur M., Sharma I. Kaur R. and G A (2014) checklist of resupinate, non-poroid agaricomycetous fungi from Himachal Pradesh, India. Synopsis Fungorum 32 8-37

Dwivedi S., Tiwari M. K., Chauhan U.K. and Pandey A.K. (2012) Biodiversity of mushrooms of Amarkantak biosphere reserve forest of Central India. International Journal of pharmacy and LIFE SCIENCES3(1)1363-1367.

Hanson J.R. (2008). The Chemistry of Fungi. The Royal Society of Chemistry, Cambridge, UK.

Hawksworth D.L. and Lucking R (2017) Fungal diversity revisited: 2.2 to 3.8 million Species. Microbiol Spectr 5: FUNK-0052-2016

Hibbett D.S., Binder M., Bischoff J.F. et al (2007). A higher-level phylogenetic classification of the Fungi. Mycological Research 111: 509-547.

Hoffmeister D. and Keller N.P. (2007). Natural products of filamentous fungi: enzymes, genes and their regulation. Natural Product Reports. 24(2): 393 416.

Jakubowska J. (1977). Itaconic and itatartaric acid biosynthesis. In: Smith, J.E. and Pateman, J.A. (eds.) Genetics and Physiology of Aspergillus. Academic
Press, London, New York and San Francisco.

Jamaluddin, Goswami M.G. and Ojha B.M. (2004). Fungi of India 1989-2001. Scientific Publishers, Jodhpur, India. $326 \mathrm{p}$.

Kamal. 2010. Cercosporoid fungi of India, Bishan Singh Mahendra Pal Singh Publication, Dehradun (UK), India, pp 351.

Karwa A and Rai MK (2010) Tapping into the edible fungi biodiversity of Central India. Biodiversitas 11(2): 97-101.

Kaushik P. and Malik A. (2009). Fungal dye decolourization: Recent advances and future potential. Environment International. 35(1): 127-141

Léveillé J. H. 1846. Descriptions des champignons de l'herbier du Muséum de Paris. Annales des Sciences Naturelles Botanique. 5:249305Saccardo P. A. (1884). Sylloge Fungorum: Sylloge Sphaeropsidearum et Melanconiearum. Sylloge Fungorum 3: $1-840$.

Li, Y., Liu, D., Cen, S., Proksch, P., and Lin, W. (2014). Isoindolinone-type alkaloids from the sponge-derived fungus Stachybotrys chartarum. Tetrahedron 70, 7010-7015. doi: 10.1016/j.tet.2014.07.047

Liaud N., Giniés C., Navarro D., Fabre N., Crapart S., Herpoël- Gimbert I., Levasseur A., Raouche S. and Sigoillot J.-C. (2014). Exploring fungal biodiversity: organic acid production by 66 strains of filamentous fungi. Fungal Biology and Biotechnology 1:1.

Lopez-Garcia R. (2002). Citric Acid. In: KirkOthmer Encyclopedia of Chemical Technology, doi: 10.1002/0471238961.03092018021201 09.a01.pub2 (http://mrw.interscience.wiley.com/emr w/9780471238966/home/), John Wiley and Sons, Inc. 
Ma, X., Zhu, T., Ba, M., Li, G., Gu, Q., Guo, Y., et al., (2013). Phenylspirodrimanes with anti-HIV activity from the spongederived fungus Stachybotrys chartarum MXH-X73. J. Nat. Prod. 76, 22982306. doi: 10.1021/np400683h

Maciel M.J.M., Castro e Silva A. and Ribeiro H.C.T. (2010). Industrial and biotechnological applications of ligninolytic enzymes of the basidiomycota: A review. Electronic Journal of Biotechnology. 13(6). doi: 10.2225/vol13-issue6-fulltext-2.

Magnuson J.K. and Lasure L.L. (2004). Organic Acid Production by Filamentous Fungi In: Tkacz J.S. and Lange L. (eds.) Advances in Fungal Biotechnology for Industry, Agriculture and Medicine. Kluwer Academic/Plenum Publishers.

Mäkelä M., Galkin S., Hatakka A. and Lundell T. (2002). Production of organic acids and oxalate decarboxylase in lignin-degrading white rot fungi. Enzyme and Microbial Technology. 30(4): 542-549.

Mandal S.K. and Banerjee P.C. (2006). Oxalic acid production by Aspergillus niger: Influence of hydrogen ion concentration and nitrogen source. Research Journal of Microbiology. 1(2): 190-197.

Mathur R. S. 1979. The Coelomycetes of India. Bishen Singh Mahendra Pal Singh, Dehradun. 460 pp.

Mitra M. (1921). Morphology and parasitism of Acrothecium Penniseti n. sp. (A new

Mitra M. (1923). Helminthosporium spp. on cereals and sugarcane in India. Part 1. (Diseases of Zea Mays and Sorghum vulgare caused by species of Helminthosporium). Mem. Dept. Agr. India, Bot. Ser. LXI: 219-242.

Mitra M. (1931). A comparative study of species and strains of Helminthosporium on certain Indian cultivated crops. Transactions of the British Mycological Society. 15: 286.

Mitter J.H. and Tandon R.N. (1930). Fungus flora of Allahabad. Journal of Indian Botanical Society. 9: 190-198.

Mitter J.H. and Tandon R.N. (1932). Fungus flora of Nainital- I. Journal of Indian Botanical Society. 11: 178-180.

Mitter J.H. and Tandon R.N. (1938). Fungi of Nainital Part- II. Journal of Indian Botanical Society. 17: 177-182.

Mitter J.H. and Tandon R.N. (1937). Fungi of Allahabad India. Part- III. Proceedings of Indian Academy of Science. 6: 194201.

Moore D., Robson G.D. and Trinci A.P.J. (2011). 21st Century Guidebook To Fungi. Cambridge University Press. UK.

Mukerji K.G. and Manoharachary C. (2010). Taxonomy and Ecology of Indian Fungi. I.K. International Publishing House Pvt. Ltd. New Delhi.

Mukerji K.G. and Juneja R.C. (1974). Fungi of India. Emkey Publications, Delhi.

Mundkur B.B. (1938). Fungi of India. Suppl. I. Monogr. Imp. Counc. Res. New Delhi 12:1-54.

Muthumary J. (1986c). Heteropatella Indica Muthumary sp. nov. from India. Current Science 55: 250-251.

Muthumary J. (1987b). New records of Coelomycetes from India. Current Science. 56: 1245-1247.

Muthumary J. (1999). First contribution to a Monograph of Septoria Species in India. Centre for Advanced Studies in Botany, University of Madras, Chennai. $119 \mathrm{pp}$.

Muthumary J. and Masilamani S. (1989). Additions to Coelomycetes of India. Journal of Indian Botanical Society 68: 131-133.

Muthumary J. (1986a). Conostroma quercicola $\mathrm{sp}$. nov. from India. Current Science. 55: 1081-1082. 
Muthumary J. (1986b). Pilidium acerinum Kunze, a new generic record for India. Current Science. 55: 791-792.

Muthumary J. (1987a). Pseudolachnea longiciliata (Hino and Katumato) Sutton new record for India. Current Science. 56: 306-307.

Muthumary J. (1987c). Notes on Cytosphaera mangiferae. Current Science 56: 426427.

Muthumary J. 2013. Indian Coelomycetes. M. J. P. Publishers, New Delhi. 365 pp

Muthumary J. and B. C. Sutton. 1986. Coryneum quercinum sp. nov. on Quercus albafrom India. Transactions of the British Mycological Society 86: $512-515$.

Pang, X., Lin, X., Tian, Y., Liang, R., Wang, J., and Yang, B. (2018). Three new polyketides from the marine spongederived fungus Trichoderma sp. SCSIO41004. Nat. Prod. Res. 32, 105111.

doi: 10.1080/14786419.2017.1338286

Pointing S.B., Pelling A.L., Smith G.J.D., Hyde K.D. and Reddy C.A. (2005). Screening of basidiomycetes and xylariaceous fungi for lignin peroxidase and laccase gene-specific sequences. Mycological Research. 109(1): 115124.

Prasher I.B. and Lalita (2013) A Checklist of Wood rotting fungi (non-gilled Agaricomycotina) of Uttarakhand. Journal on New Biological Reports 2(2): 108-123.

Prasher I.B., Lalita and Deepali A. (2012) Polyporoid fungi of District Mandi (Himachal Pradesh). J Indian Bot Soc 91(1\&2)384-386.

Pushpa H. and Purushothama K.B. (2012) Biodiversity of mushrooms in and around Bangalore (Karnataka), India. American Eurasian Journal of Agricultural and Environmental Sciences, 12(6): 750-759.
Ramakrishnan Ayyar T. S. (1941). Root rot of Sugarcane. Current Science. 10: 254255.

Ramakrishnan Ayyar T. S. (1949). Studies on the genus Colletotrichum-IV. Leaf spot of Arundo donax caused by Colletotrichum falcatum Went. var. arundinis var. nov. Proceedings of Indian Academy of Sciences. 29: 289294

Rao V. and de Hoog G.S. (1986). New or critical Hyphomycetes from India. Studies in Mycology. 28: 1-84.

Rincão, V. P., Yamamoto, K. A., Ricardo, N. M., Soares, S. A., Meirelles, L. D., Nozawa, C., et al., (2012). Polysaccharides and extracts from Lentinula edodes: structural features and antiviral activity. Virol. J. 15, 37. doi: 10.1186/1743-422X-9-37

Safari Sinegani A.A., Emtiazi G. and Hajrasuliha S. (2006). Comparative studies of extracellular fungal laccases under different conditions. Journal of Agricultural Science and Technology. 9(1): 69-76.

Sarbhoy A.K., Varshney J.L. and Agarwal D.K. (1986). Fungi of India (19771981). Navyug. Traders, New Delhi.

Sarbhoy A.K., Varshney J.L. and Agarwal D.K. (1996). Fungi of India (19821992). CBS Publisher and Distributors, New Delhi, India.

Semwal KC, Stephenson SL, Bhatt VK and Bhatt RP 2014 Edible mushrooms of the Northwestern Himalaya, India: a study of indigenous knowledge, distribution and Biodiversity of Edible Fungi: A Review diversity. Mycosphere 5(3): 440-461.

Senthilarasu G 2014 Diversity of Agarics (gilled mushrooms) of Maharashtra, India. Current Research in Environmental and Applied Mycology 4(1): 58-78.

Sharma R, Rajak Ram C and Pandey A K 
(2009a) Podaxis pistillaris: a rare Gasteromycetes from Central India. Mushroom Research, 18(1)37-38.

Sharma R, Rajak Ram C and Pandey A K (2009b) Ectomycorrhizal mushrooms in Indian tropical forests. Biodiversity 10(1): 25-30.

Sharma R, Rajak RC and Pandey AK (2011a) Dynamics of acid phosphatase production of the ectomycorrhizal mushroom Cantharellus tropicalis. Journal of Agricultural Technology. 7(1): 149-159.

Sharma R, Rajak RC and Pandey AK (2011b) Ectomycorrhiza like interaction between Cantharellus tropicalis and Dendrocalamus strictus. Journal of Agricultural Technology7(2): 413-421.

Shenoy B.D., Jeewon R. and Hyde K.D. (2007). Impact of DNA sequence-data on the taxonomy of anamorphic fungi. Fungal Diversity. 26: 1-54.

Subramanian C. V. and K. Ramakrishnan. 1952. Rostrospora a new genus of the Melanconiales. Journal of Madras University Sect. B 22: 66-68.

Subramanian C. V. and K. Ramakrishnan. 1953. On the nature of the sporeappendage in Neottiospora Desm. Proceedings of the Indian Academy of Sciences Section B37: 228-231.

Subramanian C. V. and K. Ramakrishnan. 1954. Alpakesa a new genus of the Sphaeropsidales. Journal of the Indian Botanical Society 33: 203-205.

Subramanian C.V. (1971). Hyphomycetes an account of Indian species except cercosporae. Indian Council of Agricultural research New Delhi.

Subramanian C.V. (1983). Hyphomycetes, Taxonomy and Biology. Academic Press, London.

Subramanian C. V. and K. Ramakrishnan. 1955. On Discella cedrelae Ramakr. T.S. and K. Journal of the Indian Botanical Society 34: 225-226.
Swapna S, Syed Abrar and Krishnappa M (2008) Diversity of macrofungi in semievergreen and moist deciduous forest of Shimoga district, Karnataka, India. Journal of Mycology and Plant Pathology, 38(1)21-26.

Tapwal A, Kumar R and Pandey S 2013 Diversity and frequency of macrofungi associated with wet evergreen tropical forest in Assam, India. Biodiversitas 14(2): 73-78.

Thambugala K.M., Hyde K.D., Tanaka K., Tian Q., Wanasinghe D.N., Ariyawansa H.A., Jayasiri S.C., Boonmee S., Camporesi E., Hashimoto A., Hirayama K., Schumacher R.K., Promputtha I. and Liu Z.-Y. (2015). Towards a natural classification and backbone tree for Lophiostomataceae, Floricolaceae, and Amorosiaceae fam. nov. Fungal Diversity. 74(1): 199-266.

Thiribhuvanamala G, Prakasam V, Manoranjitham SK and Krishnan S (2013) Seasonal occurrence of wild mushroom flora from the Western Ghat region of Tamil Nadu. Indian Phytopathology 66(1): 103-104.

Thirunavukkarasu N., Suryanarayanan T.S., Girivasan K.P., Venkatachalam A., Venkatachalam G., Ravishankar J.P. and Doble M. (2012). Fungal symbionts of marine sponges from Rameswaram, southern India: species composition and bioactive metabolites. Fungal Diversity. 55(1): 37-46.

Tian Q., Liu J.K., Hyde K.D., Wanasinghe D.N., Boonmee S., Jayasiri S.C., Luo Z.L., Taylor J.E., Phillips A.J.L., Bhat D.J., Li W.J., Ariyawansa H., Thambugala K.M., Gareth Jones E.B., Chomnunti P., Bahkali A.H., Xu J.C. and Camporesi E. (2015). Phylogenetic relationships and morphological reappraisal of Melanommataceae (Pleosporales). Fungal Diversity. 74(1): 267-324. 
Wang Y., Hyde K.D. and McKenzie E.H.C., Jiang Y.-L., Li D.-W. and Zhao D.-G. (2015). Overview of Stachybotrys (Memnoniella) and current species status. Fungal diversity. 71(1): 17-83.

Zhang, S. P., Huang, R., Li, F. F., Wei, H. X.,
Fang, X. W., Xie, X. S., et al., (2016). Antiviral anthraquinones and azaphilones produced by an endophytic fungus Nigrospora sp. from Aconitum carmichaeli. Fitotherapia 112, 85-89. doi: 10.1016/j.fitote.2016.05.013

\section{How to cite this article:}

Kiranpreet Kaur, Ramandeep Kaur, Shivani Thakur, Anuj Kumar, Harpreet Singh and Rajnish Kumar Verma. 2019. Fungi: Diversity in India and its Potential Applications. Int.J.Curr.Microbiol.App.Sci. 8(02): 2717-2725. doi: https://doi.org/10.20546/ijcmas.2019.802.318 